\title{
AJARAN SUSILA PADA TOKOH BIMA LAKON DEWA RUCI DALAM PERTUNJUKAN WAYANG KULIT UNTUK MENINGKATKAN MUTU PENDIDIKAN DI ABAD 21
}

\author{
Oleh \\ Diwan; I Nyoman Kiriana; I Made Sujanayasa \\ diwansanzaarangga@gmail; newmankiri@gmail.com, sujana.yasa@yahoo.com \\ Institut Hindu Dharma Negeri Denpasar, Indonesia
}

diterima 4 Agustus 2019, direvisi 16 September 2019, diterbitkan 1 Oktober 2019

\begin{abstract}
Abstrak
Wayang Kulit adalah salah satu masterpiece dunia karena karya seni ini mengandung beragam nilai, mulai dari falsafah hidup, etika (moral), spiritualitas, musik (gamelan, gending), hingga estetika bentuk seni yang sangat kompleks. Hal ini yang menyebabkan pementasan wayang kulit Bali bukan hanya sekedar tontonan namun juga merupakan tuntunan bagi masyarakat. Wayang menawarkan metode pendidikan yang amat menarik, karena mengajarkan nilai-nilai ajaran agama dan etika, serta nilai-nilai kehidupan yang mestinya dapat ditangkap oleh penonton melalui lakon sekaligus tokohtokohnya sebagai teladan. Seperti halnya lakon Dewa Ruci dalam pertunjukan wayang kulit. Lakon ini menggambarkan perjalanan spiritual tokoh Bima yang mencapai tingkat kesucian lahir batin. Tokoh Bima memberikan atualisasi ajaran susila antara laian: Guru Susrusa, Satya, Tri Kaya Parisudha, Wiweka dan Tapa, ajaran susila inilah yang sebagai bekal untuk meningkatkan mutu pendidikan di abad 21 ini.
\end{abstract}

Kata Kunci : Ajaran Susila, Tokoh Bima dan Wayang Kulit

\begin{abstract}
Abstrac
Wayang Kulit is one of the world's masterpieces because it contains a variety of values, ranging from life philosophy, ethics (moral), spirituality, music (gamelan, gending), to the aesthetics of very complex art forms. This has led to the staging of Balinese shadow puppets not only as a spectacle but also as a guide for the community. Wayang offers a very interesting educational method, because it teaches the values of religious and ethical teachings, as well as the values of life that should be captured by the audience through the play as well as the characters as role models. Like the play Dewa Ruci in the shadow puppet show. This play illustrates the spiritual journey of the Bima character who attains the level of inner and outer chastity. Bima's figure gives anualization of moral teachings between others: Guru Susrusa, Satya, Tri Kaya Parisudha, Wiweka and Tapa, this moral teaching is the provision to improve the quality of education in the 21 st century.
\end{abstract}

Keywords: Teachings of Susila, Bima Figures and Wayang Kulit 


\section{A. Pendahulun}

Wayang kulit telah berkembang menjadi suatu sistem seni yang kompleks dan mempunyai fungsi penting bagi kehidupan masyarakat terutama masyarakat Hindu di Bali. Selain erat kaitanya dengan pelaksanaan yadnya, di dalamnya tergabung secara harmonis berbagai jenis cabang seni antara lain: seni tari, seni tembang, seni kerawitan, seni sastra, dan seni drama. Melalui lakon yang dipentaskan dalam pertunjukan wayang kulit, tercermin nilai-nilai budaya yang menjadi modal dasar kebudayaan Indonesia umumnya dan kebudayaaan Bali khususnya.

Amir (1997:19) mengatakan bahwa sangat banyak ajaran dan nilainilai luhur yang terkandung di dalam lakon-lakon yang dipentaskan pada pertunjukan wayang kulit. Banyak ajaran dan nilai-nilai luhur terkandung dalam lakon-lakon yang dipentaskan pada pertunjukan wayang kulit, dan kayanya wayang dengan nilai-nilai luhur sehingga Hazim Amir menganalogikan wayang sebagai "ensiklopedi hidup". Lebih jauh Hazim Amir (1997:19) menegaskan sebagai berikut:

Kelengkapan ajaran-ajaran dan nilai-nilai yang ada dalam wayang ini dapat dilihat dari ajaran-ajaran dan nilai-nilai wayang tentang manusia, alam, dan Tuhan, serta sebagaimana manusia dapat mencapai kesempurnaan hidupnya.... Oleh karena alasan-alasan itu amat wajarlah kalau bangsa Indonesia melihat wayang sebagai sumber pencarian nilai-nilai etis yang amat lengkap.
Pendapat di atas diperkuat oleh Seramasara (2006:182) yang mengatakan pertunjukan wayang bukan hanya sebagai kreativitas budaya yang hanya menampilkan unsur-unsur estetika agar dapat disebut seni, tetapi lebih daripada itu, norma-norma dan nilai-nilai kehidupan yang dijadikan pedoman prilaku hampir seluruhnya tercermin dalam pertunjukan wayang kulit.

Menginjak ketika dunia pendidikan menghadapi bebagai tantang, dizaman yang serba digital ini, yakni memasuki abad 21 untuk meningkatkan kualitas mutu pendidikan merupakan salah satu jalan yang mesti dilakukan. Mengkaji dan memberikan pemahan yang lebih instensif tekait adanya ajaran yang tersirat dalam karya sasrtra atau pun pertunjukan tradisional yang serat nilai-nilai pendidikan yang adiluhung.

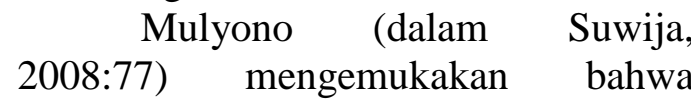
pertunjukaan wayang kulit telah menjadi kesenian klasik atau tradisional yaitu suatu seni budaya yang dihayati sepanjang masa serta di junjung tinggi dari satu generasi ke generasi berikutnya. Sebagai suatu bentuk seni klasik atau seni tradisional, wayang kulit memiliki unsur-unsur sebagai berikut: (a) seni, (b) kejiwaan, da'wah dan upacara agama/magis riligius, (c) pendidikan dan mass-media, (d) ilmu pengetahuan sastra-budaya, dan (e) hiburan.

Menurut Sujarno, dkk (2003:49), sebagai seni pertunjukan tradisional, wayang kulit memiliki empat fungsi utama, yakni : (1) fungsi ritual, (2) fungsi pendidikan atau tuntunan, (3) fungsi penerangan dan kritik sosial, serta (4) fungsi hiburan atau tontonan. Dipihak lain Waluyo (2000:73-74), 
ADI WIDYA: Jurnal Pendidikan Dasar FAKULTAS DHARMA ACARYA INSTITUT HINDU DHARMA NEGERI DENPASAR
Volume. 4, Nomor 2 Oktober 2019

ISSN: 2685-8312 (online)

ISSN: 2527-5445 (cetak

http://ejournal.ihdn.ac.id/index.php/AW mengatakan bahwa setidak-tidaknya ada dua manfaat menonton pergelaran wayang kulit, yaitu: (1) untuk memperoleh ajaran etika dan moral, dan (2) memperoleh pendidikan dan penerangan.

\section{B. Pembahasan}

Tokoh Bima adalah tokoh besar dalam epos Mahabharata yang merupakan tokoh protagonis dan oleh masyarakat Bali dikenal sebagai tokoh pengemban dharma (kebenaran). Ketertarikan orang terhadap tokoh Bima membuat tokoh ini menjadi perhatian para ahli terutama ahli budaya. Semuanya itu sebagai suatu pertanda bahwa tokoh Bima telah menjadi ikon dalam berbagai lapisan masyarakat khususnya di Bali.

Menurut Linggih (2010) Bima mengungkapkan bahwa: Pertama, Bima sebagai tatanan sifat dewa ya, artinya memiliki perspektif sifat kehidupan di alam kedewaan (dewa loka), yang dapat dilihat melalui ikon kedewaan,yaitu pada kasus angkus prana, Dewa Ruci, Arca Bima, Arca Bhairawa Bima, Bima Tapa, dan Bima Swarga. Ikon kedewaan itu merupakan sifat yang dimiliki oleh para dewa dan diantara saudaranya tidak ada yang memiliki sifat-sifat seperti itu. Kedua, Bima sebagai tatanan sifat manusia manusa $y a$, artinya memiliki sifat kehidupan di alam maya pada atau alam manusia yang dapat dilihat melalui ikon kemanusiaan yang super, yaitu pada sifat kekuatan (teguh) jasmani dan rohani, jujur, bijaksana, lembut (keibuan), dan taat (setia). Berbagai sisi kemanusiaan ini sesungguhnya jarang dijadikan bahan dalam pergolakan Bima dalam pandangan masyarakat Bali, namun justru sisi negatif lebih banyak. Ketiga Bima sebagai tatanan sifat kebutaan (buthakala), artinya memiliki sifat keraksasaan. Hal itu dapat dilihat pada sifat Bima, ke-akuan, keangkuhan, lobha/rakus, dan mengawini raksasi Hidimbi dan dapat diduga pula waktu sifat butha lebih dominan menguasai dirinya.

Terlepas dari marginalisasi masyarakat terhadap tokoh Bima, dimana pemaknaan tokoh Bima yang terlanjur diterima dalam masyarakat Bali, merupakan pemaknaan sepihak yang lebih menonjolkan sisi bentuk dari sifat-sifat keraksasaannya. Sesuai dengan pendapat Linggih di atas, sesungguhnya sifat-sifat dewa dan sifatsifat lainnya perlu dimunculkan. Seperti yang terlihat pada lakon Dewa Ruci justru Bima lebih banyak menampilkan karakter yang mencerminkan tataran dewa ya, memiliki perspektif sifat kehidupan di alam kedewaan dan manusa ya sehingga dapat bertemu dengan Dewa Ruci, dimana pertemuan ini di simboliskan dengan kemanungalan atau moksa, Tokoh Bima pada lakon Dewa Ruci dalam pertunjukan wayang kulit merupakan transformasi kesusilaan. Dengan kata lain ada nilai-nilai susila yang perlu diteladani dari tokoh Bima pada lakon Dewa Ruci ini .

\section{a. Guru Susrusa}

Guru susrusa berarti hormat kepada guru. Guru susrusa merupakan salah satu bagian dari ajaran panca yama brata (lima macam prilaku yang patut dikendalikan menuju ke arah kesempurnaan). Bentuk ajaran ini tercermin pada kesetiaan dan ketaatan tokoh Bima menjalakan perintah guru. Seperti apa yang dilakukan oleh Bima pada pertunjukan wayang, yang sedia menjalankan perintah gurunya mencari Tirta amerta. Bima perlu dijadikan contoh, khususnya bagi para siswa jaman sekarang. Bima yang sangat taat 
ADI WIDYA: Jurnal Pendidikan Dasar FAKULTAS DHARMA ACARYA INSTITUT HINDU DHARMA NEGERI DENPASAR
Volume. 4, Nomor 2 Oktober 2019

ISSN: 2685-8312 (online)

ISSN: 2527-5445 (cetak

http://ejournal.ihdn.ac.id/index.php/AW dan bhakti terhadap gurunya. Kemanapun disuruh dia mau, bahkan sampai kedasar samudra untuk mendapatkan Tirtha Amerta itu.

\section{Bhagawadgita}

III.19

menganjurkan dalam melaksanakan sesuatu (kerja), sebagai kewajiban dan tanpa terikat pada hasilnya dengan kata lain melakukan kerja atas nama Tuhan (Triguna dkk, 2009:16). Selain itu seseorang tidak boleh setengahsetengah dalam melaksanakan kewajiban (Mantra, 1994:55).

Guru susrusa artinya patuh untuk mengikuti dan menerapkan ajaran sang guru. Jika itu dilakukan maka kesuksesan menjadi milik para pelakunya (Subagiastra, 2007:8). Taitriya Upanisad mengajarkan "Matru deva bhavo, pitru devo bhavo, acarya devo bhavo, atiti devo bhavo", hormatilah ibumu, hormatilah ayahmu, hormatilah gurumu, hormatilah tamu sebagai perwujudan Tuhan di muka bumi ini Selain itu Palguna (2008:64) menyebutkan empat guru yang harus dihormati yang disebut catur guru yakni, Sang Hyang Widhi/Tuhan Yang Maha Esa (guru swadyaya), guru yang memberikan pelajaran di sekolah (guru pengajian), orang tua yang memberikan kehidupan tubuh (guru reka), dan pemerintah (guru wisesa). Dengan demikian secara luas taat dan bhakti kepada guru yang dimaksud, tidak hanya dilakukan kepada guru yang ada di sekolah saja, namun kepada catur guru.

Di dalam Guru Susrusa terkandung beberapa unsur yakni sikap hormat, ketaatan, ketulusan dan tanggung jawab. Sikap hormat merupakan sikap dan prilaku yang menghargai orang lain siapapun dia tampa memandang kedudukan, kekayaan, dan kekuasaanya, ini diwujudkan dalam perilaku yang sopan santun serta meninggikan derajat orang lain (Titib dan Sapariani, 2004:230). Perilaku ini diwujudkan dalam hubungannya dengan diri sendiri. Sebagaimana yang terdapat dalam sloka berikut:

Priyam ma krnu devesu priyam rajasu ma krnu,

Priyam sarvasya pasyata uta sudra utaye (Atharvaveda XIX. 62.1)

Terjemahanya :

Ya Tuhan Yang Maha Esa, semoga kami dicintai dan menghormati oleh para dewata dan para pemimpin bangsa. Semoga kami dikasihi oleh semuanya, siapa pun yang memperhatikan (memahami) kami, apakah seorang pengusaha ataukah seorang pekerja.

Dalam lakon Dewa Ruci ditunjukan oleh tindakan dari Bima yang menerima dan menjalankan tugas dari guru Drona dengan penuh ketaatan, ketulusan serta tanggung jawab terhadap tugas tersebut. Ketika Bima diperintahkan oleh guru Drona untuk mencari Tirtha Amerta (upaya untuk menyingkirkan Bima dari Pandawa) hingga dua kali perjalanan dengan berbagai hambatan dan rintangan yang dihadapi, Bima tetap saja setia dan taat kepada perintah guru Drona. Ia tetap sopan dan tidak sedikit pun merasa mengeluh, apalagi menolak perintah guru. Bima dengan tekad yang bulat harus mendapatkan Tirtha Amerta untuk memenuhi permintaan guru Drona.

\section{b. Satya}

Satya berarti kejujuran, kebenaran dan kesetiaan (Suhardana, 2008:30). Bima pada lakon Dewa Ruci dalam pertunjukan wayang kulit 
ADI WIDYA: Jurnal Pendidikan Dasar FAKULTAS DHARMA ACARYA

INSTITUT HINDU DHARMA NEGERI DENPASAR
Volume. 4, Nomor 2 Oktober 2019

ISSN: 2685-8312 (online)

ISSN: 2527-5445 (cetak

http://ejournal.ihdn.ac.id/index.php/AW memiliki karakter jujur. Titib (2006:130-131) mengatakan, bahwa jujur adalah sikap dan prilaku yang tidak suka berbohong dan berbuat curang, berkata-kata apa adanya dan berani mengakui kesalahan serta rela berkorban untuk kebenaran. Hal ini di wujudkan oleh tokoh Bima dengan prilaku yang tidak suka berbohong dan berbuat curang, serta rela berkorban untuk mempertahankan kebenaran.

Pustaka suci Sarasamuscaya sloka 128 (Kadjeng dkk, 1999:105) menyebutkan keberadaan satya (kejujuran, kebenaran) dalam tubuh, sebagai berikut:

Amrtam caiva mrtyucca dvayam dehe pratistitam, Mrturapadyate mohat satyenapaddyate mrtam.

Tan madoh marikang wisa, mwang amrta, ngke ring carira kahananya, kramanya, yan apunggung ikang wwang jenek ring adharma, wisa katemu denya, yapwan ateguh ring kasatyan, mapageh ring dharma, katemung amrta.

Terjemahannya:

Tak berjauhan bisa (racun) itu dengan amrta; disinilah, dibadan sendirlah tempatnya; keterangannya, jika orang bodoh dan senang hatinya kepada adharma, bisa atau racun di dapat olehnya; sebaliknya kokoh berpegang kepada kebenaran, tidak goyah hatinya bersandar kepada dharma, maka amrtalah diperolehnya.

Pada kutipan sloka diatas dikatan bahwa siapapun yang berpegang teguh pada satya /kejujuran akan mendapatkan amerta dari kejujurnya.
Pada lakon Dewa Ruci dalam pertunjukan wayang kulit nilai susila yang paling nampak adalah satya. Bima yang berpegang teguh pada kejujuranya pada akhirnya bertemu dengan Dewa Ruci dan mendapatkan Tirtha Amerta.

Hal tersebut di atas mengingatkan kepada siswa bahwa siapa saja yang berpegang teguh pada "satya" kejujuran, kebenaran dia akan dilindungi oleh"satya" kejujuran, kebenaran itu sendiri. Dalam ajaran agama Hindu ada lima macam kejujuran yang disebut panca satya, yakni: jujur pada hati nurani (satya hredaya), jujur kepada apa yang telah di ucapkan (satya wacana), jujur kepada apa yang telah dilaksanakan (satya laksana), jujur dan setia kepada janji (satya semaya), jujur dengan teman (satya mitra) (Atmaja dkk, 2010:72-73). "Satya mukyaning dharma" hendaknya Satya selalu dilaksanakan dan dikedepankan (geguritan Dharma Prawretti).

\section{c. Tri Kaya Parisudha}

Tri Kaya Parisudha berasal dari kata tri yang artinya tiga, kaya berarti prilaku atau perbuatan, dan parisudha berarti baik, bersih, suci atau disucikan. Tri kaya parisudha adalah tiga perbuatan yang harus disucikan. Perbuatan yang dimaksud adala manacika/pikiran yang baik, wacika/perkataan yang baik dan kayika/perbuatan yang baik (Suhardana, 2008:24-25). Sukartha dkk (2004:62) mengatakan dengan adanya pikiran yang baik akan timbul perkataan yang baik, sehingga terwujudlah perbuatan yang baik. Jadi intinya ada pada pikiran, dengan pikiran yang baik orang dapat berkata baik dan dengan pikiran yang baik pula, orang dapat berbuat baik.

Tentang bagaimana berpikir, berkata dan berbuat yang baik, dijelaskan dalam 
Sarasamuscaya sloka 73-76: sebagai berikut:

Hana karmapatha ngaranya, kahrtaning indriya, sapuluh kwehnya, ulahakena, kramanya, prawrettyaning manah sakareng, telu kwehnya; ulahaning wak, pat, prawrttyaning kaya, telu, pinda sapuluh, prawrttyaning kaya, wak, manah kengeta (Sarasamuscaya. 73).

Terjemahanya:

Adalah karmapatha namanya, yaitu pengendalian hawa nafsu, sepuluh banyaknya yang patut dilaksanakan; perinciannya; gerak pikiran, tiga banyaknya; prilaku perkataan, empat jumlahnya; gerak tindakan; tiga banyaknya; jadi sepuluh banyaknya, perbuatan yang timbul dari gerakan badan, perkataan dan pikiran; itulah patut diperhatikan (Kadjeng, 1999:61-62).

Prawrttyaning manah rumuhun ajarakena, telu kwehnya, pratekanya, si tan engin adengkya ri drbyaning len, si tan krodha, ring sarwa sattwa, si mamituhwa ri hana ning karmaphala, nahan tang tiga ulahaning manah, kahrtaning indriya ika (Sarasamuscaya. 74).

Terjemahnya :

Tindakan dari gerak pikiran terlebih dulu akan dibicarakan, tiga banyaknya, perinciannya: tidak ingin dan dengk pada kepunyaan orang lain, tidak bersikap gemaskepada segala makhluk, percaya akan kebenaran ajaran karmaphala, itulah ketiganya prilaku pikiran yang merupakan pengendalian hawa nafsu (Kadjeng, 1999:62).

Nyang tanpa prawrttyaning wak, pat kwehnya, pratekanya, ujar ahala, ujar aprgas, ujar picuna, ujar mithya, nahan tang pat sinanggahaning wak, tan ujarakena, tangangenangenan, kojaranya (Sarasamuscaya. 75).

Terjemahnya:

Inilah yang tidak patut timbul dari kata-kata, empat banyaknya, yaitu perkataan jahat, perkataan kasar menghardik, perkataan memfitnah, perkataan bohong (tak dapat dipercaya); itulah keempatnya harus disingkirkan dari perkataan, jangan diucapkan, jangan dipikir-pikir akan di ucapkan (Kadjeng, 1999:63).

Nihan yang tan ulahakena, syamatimati mangahalahala, si paradara, nahan tang telu tan ulahakena ring asing ring parihasa, ring apatkala, ri pangipyan tuwi singahana jugeka (Sarasamuscaya. 76).

Terjemahnya :

Inilah yang tidak patut dilakukan: membunuh, mencuri, berbuat zina; ketiganya itu jangan hendaknya dilakukan terhadap siapapun, baik secara berolokolok, bersenda gurau, baik dalam keadaan dirundung 
ADI WIDYA: Jurnal Pendidikan Dasar

FAKULTAS DHARMA ACARYA

INSTITUT HINDU DHARMA NEGERI DENPASAR
Volume. 4, Nomor 2 Oktober 2019

ISSN: 2685-8312 (online)

ISSN: 2527-5445 (cetak

http://ejournal.ihdn.ac.id/index.php/AW malang, keadaan darurat dalam khayalan sekalipun, hendaknya dihindari saja ketiganya itu (Kadjeng, 1999:63

Kutipan sloka di atas menyatakan ada sepuluh macam pengendalian prilaku yang disebut dengan karmapatha, terdiri dari tiga jenis pikiran baik, yakni: tidak ingin dan dengki pada kepunyaan orang lain, tidak bersikap gemas kepada segala makhluk, dan percaya akan kebenaran ajaran karmaphala. Yang tidak patut timbul dari kata-kata, yaitu: perkataan jahat, perkataan kasar menghardik, perkatan memfitnah, perkataan bohong (tidak dapat dipercaya). Sedangkan perbuatan yang tidak patut dilaksanakan, yaitu: membunuh, mencuri dan berbuat zina.

Dalam pertunjukan wayang kulit lakon Dewa Ruci, Bima menerima perintah Drona untuk mencari Tirtha Amerta dengan penuh kesadaran sebagai seorang murid yang taat dan bakti kepada gurunya. Perintah guru adalah kebenaran bagi Bima. Tidak ada pikiran buruk yang menggoda keyakinan Bima untuk menjalankan perintah tersebut sebagai perintah kebenaran, walaupun tugas tersebut adalah strategi Drona untuk menyingkirkan Bima dari Pandawa. Dengan keteguhan hatinya tetap berusaha mencari keberadaan Tirtha Amerta, termasuk berkata jujur ketika dia tidak menemukan Tirtha Amerta tersebut.
Bima itu konsisten, apa yang dipikirkan, demikian pula yang dikatakan dan dilaksanakan. Pada lakon Dewa Ruci, Bima selalu berpikir positif itulah positif thinking yang dimiliki Bimaa. Ketika dinasehati oleh Yudistira dia tetap pergi mencari Tirtha Amerta yang tidak ada dunia ini. Tapi dengan pikiran positifnya, kejujurannya dan ketaatannya menjadi seorang siswa, hakhirnya bertemulah Bima dengan Dewa Ruci yang menganugrahkan Tirtha Amerta itu. Itulah kekuatan pikiran, makanya jangan berpikir yang buruk, karena bisa menjadi kenyataan. Berpikirlah yang positif, jujur dan laksanakan kewajiban dengan dengan penuh tanggung jawab berlandaskan "satya" kebenaran .

\section{d. Wiweka}

Menurut Subagiastra (2007:12), wiweka artinya prilaku yang waspada penuh pertimbangan serta kehati-hatian. Selanjutnya dijelaskan hal positif atau baik dan buruk menjadi dasar bertindak. Tidak terjadinya kecerobohan dan kefatalan dalam bertindak, oleh hal yang negatif atau keburukan sedapat mungkin untuk dilakukan. Perbuatan baik (subhakarma) yang diutamakan dan perbuatan buruk (asubha karma) yang dijauhi atau tidak dilakukan.

Lakon Dewa Ruci dalam pertunjukan wayang kulit diceritakan Bima memiliki multi karakter, antara lain setia dan taat, jujur, kuat (teguh), pemberani, keras, lembut dan bijaksana. Ajaran wiweka pada tokoh Bima dapat dilihat pada saat bagaimana Bima harus berani, saat bagaimana Bima harus keras dan pada saat bagaimana justru Bima itu harus lembut .

Kebijaksanaan Bima dapat terlihat dri pertanda yang melekakat pada wayang Bima. Karakter ini tercermin pada kain poleng yang 
ADI WIDYA: Jurnal Pendidikan Dasar FAKULTAS DHARMA ACARYA INSTITUT HINDU DHARMA NEGERI DENPASAR
Volume. 4, Nomor 2 Oktober 2019

ISSN: 2685-8312 (online)

ISSN: 2527-5445 (cetak

http://ejournal.ihdn.ac.id/index.php/AW dipakai oleh tokoh Bima. Kain poleng melambangkan kejujuran dan kebijaksanaan, dimana warna poleng terjadi sebagai hasil perpaduan yang harmonis antara warna hitam dan warna putih. Keharmonisan terjadi akibat, seberapa jumlah warna putihnya, sekian pula warna hitamnya. Jumlah warna yang sama ini melambangkan bahwa pikiran tokoh Bima berada dalam posisi seimbang. Seimbang disini dapat diartikan bahwa tokoh Bima dalam memutuskan suatu permasalahan sangat bijaksana atau seimbang dan tidak berat sebelah.

Kebijaksanaan tokoh Bima sangat jelas diperlihatkan ketika Bima dihadapkan dengan berbagai pertimbangan dan masalah-masalah selama perjalanan mencari Titha Amerta, sehingga ia harus memutuskan apa yang mesti dia lakukan. Mulai dari pertimbangan Yudistira yang sudah menaruh curiga pada perintah guru Drona. Bima dihadapkan dengan dua pilihan menolak perintah kakaknya (Yudistira) atau menolak perintah guru Drona. Dengan bijaksana akhiranya Bima memutuskan tetap pergi mencari Tirtha amerta.

Dalam hal ini "wiweka" pertimbangan memunculkan kebijaksanaan. Melalui lakon Dewa Ruci, prilaku yang waspada penuh pertimbangan serta kehati-hatian inilah yang ingin disampaikan oleh dalang kepada penonton pada umumnya dan khusunya peseta didik..

\section{e. Tapa}

Tapa merupakan salah satu ajaran Dasa Nyama Brata (Suhardana, 2008:31) yang artinya adalah pengekangan nafsu, tahan banting. Dalam ajaran ini terkandung beberapa unsur di dalamnya yakni kerja keras, tekun, ulet, dan pantang menyerah.
Kerja keras merupakan sikap dan perilaku yang menujukkan dalam melakukan suatu kegiatan dengan sekuat tenaga, tanpa mengenal lelah, bertahan dan sampai tuntas. Hal ini diwujudkan dengan perilaku yang melakukan sesuatu menggebu-gebu, tidak kenal lelah dan istirahat sampai akhir pekerjaan (Titib dan Sapariani, 2004). Perilaku ini diwujudkan dalam hubungannya dengan diri sendiri, keluarga dan masyarakat atau bangsa. Dalam ajaran Hindu kerja keras yang dimaksud adalah berdasarkan atas dharma (Sarasamuscaya. 12). Kitab suci Weda menyebutkan sebagai berikut:

Kurvam eveha karmani
jijiviset satam samah
Eavam tvayi nanyatheto-asti na karma lipyate nare (Yajurveda XL.2) Terjemahan:

Orang seharusnya suka hidup di dunia ini dengan melakukan kerja keras selama seratus tahun. Tidak ada cara yang lain bagi keslamatan seseorang. Suatu tindakan yang mementingkan diri sendiri dan tidak memihak menjauhkan pelaku dari keterikatan.

Lakon Dewa Ruci dalam pertunjukan wayang kulit memberikan pesan kepada penonton bahwa untuk mencapai tujuan maka dipentingkan kerja keras. Seperti halnya tokoh Bima yang selalu memiliki semangat bekerja keras dalam menjalankan perintah guru Drona untuk mendapatkan Tirtha Amerta. Kerja keras Bima tercermin dari ketangguhannya dalam melaksanakan tugas gurunya. Tidak hanya secara fisik namun tangguh dan kuat secara mental.

Bima itu merasa dengan dirinya bodoh, tetapi dengan keteguhan hati dan pendirian yang kuat, dia siap menerima 
ADI WIDYA: Jurnal Pendidikan Dasar FAKULTAS DHARMA ACARYA INSTITUT HINDU DHARMA NEGERI DENPASAR
Volume. 4, Nomor 2 Oktober 2019

ISSN: 2685-8312 (online)

ISSN: 2527-5445 (cetak

http://ejournal.ihdn.ac.id/index.php/AW tugas berat yang diberikan oleh gurunya. Secara tidak langsung tokoh Tualen mengatakan bahwa Bima merupakan sosok yang luar biasa yang memiliki karakter kuat secara mental. Hal tersebut merupakan gambaran, bahwa Bima memang memiliki mental yang kuat. Semua keberhasilan yang dicapai oleh Bima itu mencerminkan bahwa ia tidak semata-mata menghandalkan kekuatan fisik, tetapi yang lebih penting dan utama adalah kekuatan mental dan keteguhan hati yang bulat.

Di dalam tapa juga terkandung unsur ketekunan. Tekun artinya Sikap dan perilaku yang secara konsiten dan terus menerus dilakukan tanpa dorongan dari luar melainkan sudah diinternalisasai dari dalam dirinya. Hal ini diwujudkan dalam prilaku yang tidak henti-hentinya melakukan suatu kegiatan sampai tercapainya tujuan, dengan semangat yang kosisten. Perilaku ini diwujudkan dalam hubungannya dengan diri sendiri.

Kurvam eveha karmani
jijiviset satam samah
Eavam tvayi nanyatheto-asti na karma lipyate nare (Yajurveda XL.2)

\section{Terjemahan:}

Orang seharusnya suka hidup di dunia ini dengan melakukan kerja keras selama seratus tahun. Tidak ada cara yang lain bagi keslamatan seseorang. Suatu tindakan yang mementingkan diri sendiri dan tidak memihak menjauhkan pelaku dari keterikatan.

Ulet sikap dan perilaku yang tetap bertahan meskipun menghadapi hambatanhambatan yang sangat besar atau sulit, tidak mudah putus asa sangat kuat bertahan. Hal ini diwujudkan dalam perilaku yang tidak mudah menyerah dan lekas putus asa terhadap berbagai hambatan yang dihadapi. Perilaku ini diwujudkan dalm hubunganya dengan diri sendiri.

Icchanti devah sunvantam na svapnaya sprhayanti.

Yanti pramadam atandrah. Atharvaveda XX. 18.3

\section{Terjemahannya}

Para dewa menyukai orang yang ulet dan pekerja keras, para dewa tidak menyukai orang yang gampang gampangan dan bermalasmalas. Orang-orang yang selalu waspada mencapai kebahagian yang agung

Berani memikul resiko merupakan sikap dan prilaku yang sampai batas-batas tertentu tidak takut menghadapi akibat apapun untuk mempertahankan ketetapan yang telah dipilihnya. Nilai ini diwujudkan dengan perilaku yang mau menanggung akibat apapun. Bima berani merelakan jiwa raganya demi tugas tersebut. Sebagai seorang ksatria Bima tidak pernah mundur menghadapi rintangan yang menghalanginya termasuk dalam menghadapi raksasa Rukmuka, Rukmakala dan Raja Naga Nemburnawa dengan pasukan ularnya.

\section{PENUTUP}

Ajaran susila yang terdapat pada tokoh Bima lakon Dewa Ruci dalam pertunjukaan wayang kulit untuk meningkatka mutu pendidikan di abab 21 yakni: 1) Guru Susrusa (taat dan bhakti kepada guru),2) Satya (dalam menjalani hidup harus mengedepankan kebenaran dan kejujuran, 3) Tri Kaya 
Parisuda ( Sebagai pendidik ataupun peserta didik harus mampu, berfikir, berkata dan berbuat yang baik), 4) Wiweka (mempunyai pertimbangan pertimbangan di dalam melaksanakan kehidupan), 5) Tapa (kerja keras, tekun, ulet, berani mengambil resiko.

\section{DAFTAR PUSTAKA}

Amir, Hazim. 1997. Nilai-Nilai Etis dalam Wayang. Jakarta : Sinar Harapan

Atmaja, I Made Nada dkk. 2010. Etika Hindu. Surabaya: Paramita

Kadjeng, I

Nyoman,dkk, 199.Sarascamuscaya.

Surabaya:Paramita

Linggih, I Nyoman. 2010. "Tokoh Bhima dalam Seni Rupa Di Bali: Perspektif

Kajian

Budaya”. Disertasi. Program Pasca Sarjana Universitas Udayana Denpasar.

Seramasara, I Gusti Ngurah. 2006. "Wayang Kulit Bali Diantara Tradisi dan perubhan: Sebuah Dilema dan Harapan dalam PelestarianSeni Budaya Bali”. dalam Mudra, Volume 19 . Institut Seni Indonesia Denpasar
Subagiasta, I Ketut .2007 . Etika Pendidikan agama Hindu . Surabaya:Paramitra

Suhardana,K.M 2008. Dharma Jalan Menuju Kebahagian.

Surabaya:Paramita

Sujarno, dkk. 2003. Seni Pertunjukan Tradisional : Nilai, Fungsi, dan Tantangannya

Yogyakarta: Balai Kajian Sejarah dan Nilai Tradisional

Suwija, I Nyoman. 2007. "Kritik Sosial Wayang Kulit Inovatf Bali Kajian Wacana Naratif'. Program Studi Doktor Linguistik Program Pasca Sarjana Universitas Udayana Denpasar

Titib, I Made dan Ni Ketut Supariani. 2006. Keutamaan Manusia dan Pendidikan Budhi Pekerti. Surabaya: Paramita

Waluyo, Kanti. 2000. “ Pola Prilaku Menonton Wayang Kulit", dalam Mudra No. 8 Tahun VIII. Januari 2000. Sekolah Tingi Seni Indonesia Denpasar 